\title{
Comparison of pathogenic domains of rabies and African rabies-related lyssaviruses and pathogenicity observed in mice
}

\author{
Authors: \\ Joe Kgaladi ${ }^{1}$ \\ Louis $\mathrm{H}$. Nel${ }^{1}$ \\ Wanda Markotter ${ }^{1}$ \\ Affiliations: \\ ${ }^{1}$ Department of Microbiology \\ and Plant Pathology, \\ University of Pretoria, \\ South Africa \\ Correspondence to: \\ Wanda Markotter \\ Email: \\ wanda.markotter@up.ac.za \\ Postal address: \\ Department of Microbiology \\ and Plant Pathology, \\ University of Pretoria, \\ Pretoria 0002, South Africa \\ Dates: \\ Received: 27 Aug. 2012 \\ Accepted: 24 Nov. 2012 \\ Published: 08 Mar. 2013 \\ How to cite this article: \\ Kgaladi, J., Nel, L.H. \\ \& Markotter, W., \\ 2013, 'Comparison of \\ pathogenic domains of \\ rabies and African rabies- \\ related lyssaviruses and \\ pathogenicity observed in \\ mice', Onderstepoort Journal \\ of Veterinary Research 80(1), \\ Art. \#511, 13 pages. \\ http://dx.doi.org/10.4102/ \\ ojvr.v80i1.511

\section{Copyright:} \\ (C) 2013. The Authors. \\ Licensee: AOSIS \\ OpenJournals. This work \\ is licensed under the \\ Creative Commons \\ Attribution License. \\ Read online:

Several lyssavirus species occur in Africa (Rabies virus, Lagos bat virus, Mokola virus, Duvenhage virus, Shimoni bat virus and Ikoma lyssavirus), displaying a high sequence diversity between isolates belonging to the same species. There is limited information about comparative pathogenesis of these African lyssaviruses and this precludes authoritative opinion on the potential public and veterinary health impact. In this study, an analysis of representative African lyssaviruses attempted to correlate viral genomic sequence similarities and differences with the corresponding pathogenic profiles observed in mice. The study demonstrated that the virus isolates evaluated could be lethal to mice when introduced intramuscularly and that different isolates of the same lyssavirus species differ in their virulence. Using real-time polymerase chain reaction (PCR), viral RNA was detected in brain tissue, but no viral RNA was detected in the salivary glands or blood of mice that succumbed to infection. Comparison of known pathogenic domains indicated that pathogenicity is likely to be dependent on multiple domains. Cumulatively, our results re-emphasised the realisation that the pathogenicity of a lyssavirus species cannot be deduced based on studies of only a single isolate of the species or a single pathogenic domain.

\section{Introduction}

Rabies is a fatal disease of mammals, including humans, and is caused by viruses of the genus Lyssavirus in the family Rhabdoviridae, order Mononegavirales. Currently, the Lyssavirus genus consists of twelve classified species (ICTV Official Taxonomy: Updates since the 8th Report), of which five (Rabies virus [RABV], Lagos bat virus [LBV], Mokola virus [MOKV] and Duvenhage virus [DUVV]) have been isolated in Africa. Two putative lyssavirus species, Shimoni bat virus and Ikoma lyssavirus, have recently been isolated from a bat (Hipposideros commersoni) in Kenya and an African civet (Civettictis civetta) in Tanzania, respectively (Kuzmin et al. 2010; Marston et al. 2012). LBV, MOKV and DUVV probably occur exclusively in Africa, as encounters with these viruses have not been reported from elsewhere. The African rabies-related lyssaviruses are characterised by the diversity of the limited number of isolates available within each of the virus species. In southern Africa, RABV is present in the form of two distinct variants, adapted to canines (canid variant) and to herpestids (mongoose variant) (Nel et al. 2005). Despite availability of vaccines and other rabies control measures, RABV is estimated to cause over 55000 human deaths each year - mostly in developing countries of Africa and Asia (Knobel et al. 2005). There are five different clusters of mongoose variant viruses in southern Africa ( $\mathrm{Nel}$ et al. 2005). The clusters are defined by the geographic regions in which the viruses were isolated. Isolates from more than one different mongoose species were found within a cluster. Cohen et al. (2007) reported six different clusters of canid variant viruses in southern Africa. The clusters were defined by geographic location and included virus isolates from four provinces of South Africa. Four lineages (A-D) have been described for LBV (Kuzmin et al. 2010; Markotter et al. 2008). It was indicated that lineage A only shares $79.1 \%$ nucleoprotein gene nucleotide identity with lineage B and C (Markotter et al. 2008) whilst lineage D only shares from $79.5 \%$ to $80.9 \%$ identity to all other LBV lineages (Kuzmin et al. 2010). DUVV isolates show very close sequence homology in southern Africa but DUVV isolated in Kenya in 2006 constitutes a new lineage (Van Eeden, Markotter \& Nel 2011). For MOKV several different phylogenetic groupings were observed based on geographical location (Sabeta et al. 2010).

Pathogenesis studies of RABV (canid variant) as well as other lyssavirus species such as European bat lyssavirus-1 (EBLV-1), European bat lyssavirus-2 (EBLV-2) and Australian bat lyssavirus (ABLV) in animal models are reported regularly (Dietzschold, Faber \& Schnell 2008). However, studies on the pathogenesis of lyssaviruses known to occur in Africa are limited. Although RABV is associated with most of the human and animal rabies cases reported each year, in recent years, increases in LBV, DUVV and MOKV infections have been reported 
(Markotter et al. 2008; Sabeta et al. 2010; Van Eeden et al. 2011). Improved surveillance correlates with an increase in the number of cases. Surveillance in the KwaZulu-Natal province of South Africa between 2003 and 2006 resulted in a number of LBV isolates in fruit bats (Epomophorus wahlbergi) (Markotter et al. 2008). In experimental models, lyssaviruses are lethal when inoculated intracranially but other routes of infection such as intramuscular (i.m.), which is representative of natural infection through a bite, depend on the virus isolate as well as the dose of inoculum (Badrane et al. 2001; Markotter et al. 2009). Badrane et al. (2001) showed that lyssaviruses can be divided into two phylogroups, namely phylogroup I (RABV, DUVV, ELBV-1, EBLV-2 and ABLV) and phylogroup II (LBV and MOKV). Phylogroup I was reported to be lethal through the intracranial (i.c.) and i.m. routes whilst initially phylogroup II was lethal only through the i.c. route in mice. One isolate as a representative of LBV and MOKV administered at a dose of $3 \times 10^{5} \mathrm{LD}_{50}$ and $3 \times 10^{7}$ $\mathrm{LD}_{50}$ respectively, was used. This led to the assumption that these viruses are less lethal and less of a public and veterinary health threat. However, Kemp et al. (1973) reported that shrews succumb to MOKV when inoculated via the i.m., subcutaneous and oral route of inoculation. Recently, mice were reported to succumb to LBV infection, with LBV isolates administered i.m. in doses of $10^{3}, 10^{6}$ and $10^{4.9} \mathrm{LD}_{50}$ (Kuzmin et al. 2008; Markotter et al. 2009). The same was observed for one isolate of MOKV administered at a dose of $10^{6} \mathrm{LD}_{50}$ (Markotter et al. 2009). Some of the LBV isolates and the MOKV isolate were not lethal at a lower dose of $10^{3} \mathrm{LD}_{50}$. It has been shown in experimental infections that inoculation with a high viral dose results in a higher percentage mortality than inoculation with low viral doses (Kemp et al. 1973; Markotter et al. 2009; Niezgoda et al. 1997). Lyssaviruses are commonly transmitted by a bite from a rabid animal, after which the virus is transported from the site of entry to the central nervous system where it multiplies to high amounts once in the brain. During the late stage of disease, centrifugal spread of the virus to non-neuronal tissues occurs (Warrell \& Warrell 2004). RABV, LBV and MOKV have been reported to be present in non-neuronal tissues of rabid animals: kidney, salivary glands, muscle, tongue, oral swab, ovary, vaginal swabs, adrenals, pancreas, liver, spleen and heart (Jackson et al. 1999; Kemp et al. 1973; Kuzmin et al. 2008). Viremia is considered not to occur in lyssavirus infected animals. However, viral RNA was detected in the blood of clinically ill RABV infected mice and this should be further investigated (Lodmell, Dimcheff \& Ewalf 2006). Virus neutralising antibodies (VNA) have been shown to be important in clearance of RABV infection (Hooper et al. 1998), but there are also other mechanisms that play a role in virus clearance. Hooper et al. (1998) demonstrated that in addition to VNA, inflammatory mechanisms also contribute to clearance of virus infection. Coe and Bell (1977) showed the presence of VNA in Syrian hamsters as early as day 5 post inoculation with RABV. However, clinical signs were observed from day 8 to 9 whilst death followed after 2-5 days of onset of symptoms. Mice inoculated with RABV (silver haired bat variant) were shown to succumb to infection irrespective of production of high
VNA (Roy et al. 2007). This was attributed to the inability of VNA and other immune factors to cross the blood-brain barrier. Not all animals that survive experimental infection develop VNA (Niezgoda et al. 1997; Niezgoda et al. 1998). It has been suggested that the specific virus isolate as well as the dose of inoculation could influence production of VNAs (Niezgoda et al. 1997; Niezgoda et al. 1998).

The lyssavirus genome codes for five proteins, that is the nucleoprotein $(\mathrm{N})$, phosphoprotein $(\mathrm{P})$, matrix protein $(\mathrm{M})$, glycoprotein $(\mathrm{G})$ and RNA polymerase (L). A number of domains on these proteins have been implicated in the pathogencity of these viruses. For example, the amino acids Phe 273 and Tyr 394 on the N protein of a pathogenic RABV strain have been shown to play a role in inhibition of interferon (IFN) system and chemokines (Masatania et al. 2011). Inhibition of IFN system and chemokines prevents expression of antiviral proteins at the site of infection, allowing the virus to be transported to the central nervous system. A K/RXTQT motif on the P protein was shown to be important for binding to the LC8 dynein light chain, therefore important for retrograde intracellular transport of the virus to the central nervous system (CNS) (Poisson et al. 2001). However, some studies showed that transport of RABV to the CNS also occurred in mutants where this motif was changed (Tan et al. 2007). Mutation of the PPEY motif on the M protein reduced pathogenicity of RABV when inoculated intranasally (i.n.) in mice (Gholami et al. 2008). Although domains important in pathogenicity have been indicated in several lyssavirus proteins, the $G$ protein remains the most important. Mutation of Arg/Lys 333 on the G protein was reported to result in non-pathogenic strains when inoculated i.m. (Badrane et al. 2001; Dietzschold et al. 1983). This position was thought to be the most important in determining pathogenicity. However, this assumption was challenged when the lethality of a RABV isolate could be reversed by an amino acid change elsewhere (Asn 194 to Lys) regardless of the amino acid present at position 333 in the $G$ protein (Faber et al. 2005). Another RABV virus, the RC-HL virus strain, was shown not to be lethal in mice via i.c. and i.m. route irrespective of conservation of Arg 333 (Takayama-Ito et al. 2006). However, this strain reverted to a lethal strain via the i.c. route when Leu 268 was replaced by Ile 268 (TakayamaIto et al. 2006). Different strains of mice as well as different passages of the virus strains were used in determining the importance of these pathogenic domains. Mutations such as Arg 333 on the G protein were shown to be important in pathogenicity using different passages and different strains of mice (Coulon et al. 1998; Dietzschold et al. 1983; Seif et al. 1985). These results demonstrated the importance of comparing a number of pathogenic domains when studying the pathogenicity of specific lyssavirus isolates.

In this study, the full coding regions of the $\mathrm{N}, \mathrm{P}, \mathrm{M}$ and $\mathrm{G}$ gene were sequenced for a total of 23 representative lyssavirus isolates, predominantly from southern Africa. The pathogenicity of 11 of the 23 isolates was determined by i.m. inoculation of mice and pathogenic domains between isolates were compared. 


\section{Materials and methods}

\section{Virus isolates}

A total of 23 lyssavirus isolates comprising of the four African lyssavirus species (RABV [mongoose and canid variants], LBV, MOKV and DUVV) were selected for this study (Table 1) to represent, where possible the genetic diversity especially for southern Africa, based on previous phylogenetic studies (Cohen et al. 2007; Markotter et al. 2008; Nel et al. 2005). All isolates were passaged mouse brain tissue or passaged cell culture material (passage number unknown) except for LBVSA2008 which was obtained as original bat brain suspension. Five-week-old National Institute of Health (NIH) BALB/c mice (South African Vaccine Producers, Sandringham, South Africa) were used for experimental infection.

\section{Sequencing and comparison of the ucleoprotein, phosphoprotein, matrix protein and glycoprotein coding regions of several lyssavirus isolates}

Lyssavirus sequences were either determined by previous studies (Markotter et al. 2008) or determined in this study using several primer sets and cycling conditions (available on request) (Table 1). The PCR amplicons were purified using the Wizard ${ }^{\circledR}$ PCR Preps DNA Purification System (Promega, Madison, USA). Purified PCR products were sequenced with the BigDye ${ }^{\mathrm{TM}}$ Termination Cycle Sequencing Ready Reaction Kit 3.1 (Applied Biosystems, California, USA) according to the manufacturer's protocol and analysed on an ABI 377 DNA sequencer (Applied Biosystems, California, USA). PCR products were sequenced with both the forward and the reverse primers. The complete N, P, M and G genes were sequenced. The nucleotide sequences were converted to amino acids and aligned using BioEdit sequence alignment editor v.7.0, ClustalW subroutine (Hall 1999). An alignment was made that encompasses domains on the N, P, M and G gene indicated to be important for pathogenicity. Sequences of other RABV isolates were also included (Table 1).

\section{Virus amplification and titration}

Ten per cent mouse brain suspensions were prepared in Dulbecco's Modified Eagle's Medium (DMEM-10) (Lonza, Walkersville, USA) supplemented with $10 \%$ fetal calf serum (Lonza, Walkersville, USA). The suspensions were centrifuged at $3200 \mathrm{~g}$ for $15 \mathrm{~min}$ and $0.5 \mathrm{~mL}$ of the supernatant was used to infect $2 \times 10^{6}$ mouse neuroblastoma (MNA) cells in $25 \mathrm{~mL}$ flasks (Corning Incorporated, New York, USA) followed by incubation at an atmosphere of $37{ }^{\circ} \mathrm{C}$ and $5 \% \mathrm{CO}_{2}$ for $1 \mathrm{~h}$. Thereafter, $0.3 \mathrm{~mL}$ of the infected cells was added to LabTek chamber slides (Nalge Nunc International, New York, USA) whilst the remaining was added to T25 flask together with $5 \mathrm{~mL}$ of DMEM-10 and incubated for $72 \mathrm{~h}$. After $48 \mathrm{~h}$, the presence of lyssavirus antigen on LabTek chamber slides was determined by fluorescence antibody test (FAT) (Dean, Abelseth \& Atanasiu 1996) using anti-rabies polyclonal fluorescence isothiocyanate conjugate (FITC) (Rabies Unit, Onderstepoort Veterinary Institute, Agricultural Research Council, South Africa). To determine virus yield from the T25 flask, monolayers of MNA cells $\left(2 \times 10^{6}\right)$ in LabTek chamber slides were infected with serial 10 -fold virus dilutions. The slides were incubated for $48 \mathrm{~h}$. Thereafter, the slides were fixed in cold acetone (Merck, Modderfontein, SA), stained with anti-rabies polyclonal FITC and the TCID Tetermined $_{50}$ det (Reed \& Muench 1983).

\section{Experimental infections}

Mice were put in individually labelled cages. Only 11 (Table 1, indicated by $\dagger$ ) of the 23 isolates were chosen for inoculation of mice after pathogenic domains were compared between the 23 representative African lyssavirus isolates. The number of isolates for each lyssavirus species was then reduced based on amino acid similarities in pathogenic domains. Groups of 3 to 5 mice were inoculated i.m. with $0.05 \mathrm{~mL}$ of $10^{5} \mathrm{TCID}_{50}$ of RABV (canid variant) (31/05 and 819/05), RABV (mongoose variant) (113/91), LBV (LBVSA2008 and LBVNig1956), MOKV (12341) and DUVV (DUVVSA2006). In addition to inoculation at a dose of $10^{5}$ $\mathrm{TCID}_{50}$, one LBV isolate from lineage A (LBVAFR1999) and another from lineage C (LBVMong2004) were inoculated at a higher dose of $10^{8} \mathrm{TCID}_{50}$ and LBV (LBVSA2004) and MOKV (252/97) at a dose of $10^{7} \mathrm{TCID}_{50}$. Furthermore, LBV (LBVSA2008) was inoculated at a lower dose $\left(10^{3} \mathrm{TCID}_{50}\right)$ also using $10 \%$ suspension of the original bat brain material. Mice were monitored for 60 days. Deaths and clinical signs / observations were recorded daily. The mice were euthanised with ketamine (Anaket-V) (35 mg/kg body mass) upon development of clinical signs or on day 60 in cases where clinical signs were not observed.

\section{Collection of brain, salivary glands and blood}

Brain and salivary glands were collected after the mice were euthanised or died. Necropsies were performed in class II biosafety cabinets using sterile implements. The material was stored at $-70{ }^{\circ} \mathrm{C}$ until use. Blood was collected weekly in BD Microcontainer ${ }^{\mathrm{TM}}$ (Becton Dickson, New Jersey, USA) by retro-orbital route using $80 \mu \mathrm{L}$ capillaries (Superior Marienfeld Laboratory Glassware, Germany). The blood was centrifuged at $13400 \mathrm{~g}$ for $10 \mathrm{~min}$ and serum was collected in $1.5 \mathrm{~mL}$ microcentrifuge tubes (Quality Scientific Plastics, California, USA) and stored at $-20^{\circ} \mathrm{C}$ until use. Blood clots were also stored at $-20^{\circ} \mathrm{C}$.

\section{Fluorescent antibody test and Taqman real- time polymerase chain reaction to determine the presence and quantity of viral antigen and viral RNA}

All brain samples were tested for the presence of lyssavirus antigen by FAT using polyclonal fluorescein isothiocyanate anti-lyssavirus conjugate (Dean et al. 1996). Brain and salivary gland samples of mice that succumbed to lyssavirus infection were further analysed for the presence and concentration of viral RNA by Taqman real-time PCR as described in Coertse et al. (2010). Only the blood clots of mice taken just before the mice died or were euthanised after developing clinical signs were analysed for the presence of lyssavirus 
TABLE 1: Lyssavirus isolates used in this study for amino acid comparison of pathogenic domains and experimental infection of mice.

\begin{tabular}{|c|c|c|c|c|c|}
\hline Virus isolate & Country and area of isolation & Host species & $\begin{array}{l}\text { Year of } \\
\text { isolation }\end{array}$ & $\begin{array}{l}\text { Laboratory } \\
\text { reference number }\end{array}$ & GenBank accession numbers \\
\hline RABV (canid variant) & Sibasa, South Africa (group 1)§ & $\begin{array}{l}\text { Dog } \\
\text { (Canis familiaris) }\end{array}$ & 2006 & $262 / 06$ & $\begin{array}{l}\mathrm{HM} 179504(\mathrm{~N}) \ddagger, \mathrm{HQ} 266628(\mathrm{P}) \ddagger \\
\mathrm{HQ} 266609(\mathrm{M}) \ddagger, \mathrm{HQ} 266620(\mathrm{G}) \ddagger .\end{array}$ \\
\hline RABV (canid variant) & $\begin{array}{l}\text { emKhondo, formerly Piet Retief, } \\
\text { South Africa (group 2) }\end{array}$ & $\begin{array}{l}\text { Dog } \\
\text { (Canis familiaris) }\end{array}$ & 2004 & $567 / 04$ & $\begin{array}{l}\mathrm{HM} 179505(\mathrm{~N}) \ddagger, \mathrm{HQ} 266626(\mathrm{P}) \dagger \\
\mathrm{HQ} 266607(\mathrm{M}) \div, \mathrm{HQ} 266618(\mathrm{G}) \dagger .\end{array}$ \\
\hline RABV (canid variant) & Thabazimbi, South Africa (group 3) & $\begin{array}{l}\text { Dog } \\
\text { (Canis familiaris) }\end{array}$ & 1996 & $479 / 96$ & 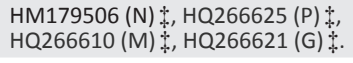 \\
\hline RABV (canid variant) $\dagger$ & Soutpansberg, South Africa (group 4) & $\begin{array}{l}\text { Black-backed jackal } \\
\text { (Canis mesomelas) }\end{array}$ & 2005 & $819 / 05$ & 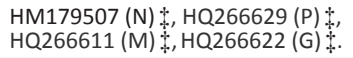 \\
\hline RABV (canid variant) $\dagger$ & Umtata, South Africa (group 7) & $\begin{array}{l}\text { Bat-eared fox } \\
\text { (Otocyon megalotis) }\end{array}$ & 2005 & $31 / 05$ & 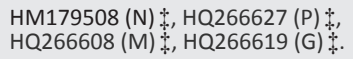 \\
\hline RABV (canid variant) & Japan & Laboratory strain & 1915 & Nishigahara & AB044824 \\
\hline RABV (canid variant) & - & SAD strain derivative & - & ERA & EF206707 \\
\hline RABV (canid variant) & USA & $\begin{array}{l}\text { Insectivorous bat } \\
\text { (Lasionycteris noctivagans) }\end{array}$ & 1983 & SHBRV-18 & AY705373 \\
\hline RABV (canid variant) & Japan & Nishigahara derivative & 1918 & $\mathrm{RC}-\mathrm{HL}$ & AB009663 \\
\hline RABV (canid variant) & China & $\begin{array}{l}\text { Human } \\
\text { (Homo sapiens) }\end{array}$ & - & Flury-LEP & FJ577895 \\
\hline RABV (canid variant) & USA & LEP-Fury derivative & 1939 & HEP-Flury & AB085828 \\
\hline RABV (canid variant) & - & Vaccine & - & PV & M13215 \\
\hline RABV (mongoose variant) & Rusape, Zimbabwe (group 1) & $\begin{array}{l}\text { Slender mongoose } \\
\text { (Galerella sanguinea) }\end{array}$ & 1994 & 22107 & $\begin{array}{l}\text { FJ392391 (N), HQ266633 (P) }+ \\
\text { HQ266615 (M) } \ddagger, \text { FJ465408 (G). }\end{array}$ \\
\hline RABV (mongoose variant) & Grootgewaagd, South Africa (group 2) & $\begin{array}{l}\text { Yellow mongoose } \\
\text { (Cynictis penicillata) }\end{array}$ & 1990 & $669 / 90$ & 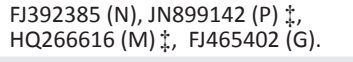 \\
\hline RABV (mongoose variant) & Kroonstad, South Africa (group 3) & $\begin{array}{l}\text { Yellow mongoose } \\
\text { (Cynictis penicillata) }\end{array}$ & 1995 & $767 / 95$ & $\begin{array}{l}\text { FJ392388 (N), HQ266630 (P) } \ddagger \\
\text { HQ266617 (M) } \ddagger, F J 465405 \text { (G). }\end{array}$ \\
\hline RABV (mongoose variant) & Uitenhage, South Africa (group 4) & $\begin{array}{l}\text { Yellow mongoose } \\
\text { (Cynictis penicillata) }\end{array}$ & 1996 & $364 / 96$ & $\begin{array}{l}\text { FJ392379 (N), HQ266632 (P) }+ \\
\text { HQ266614 (M) } \ddagger \text {, FJ465397 (G). }\end{array}$ \\
\hline RABV (mongoose variant) $\dagger$ & Beaufort West, South Africa (group 5) & $\begin{array}{l}\text { Water mongoose } \\
\text { (Atilax paludinosus) }\end{array}$ & 1991 & $113 / 91$ & $\begin{array}{l}\text { FJ392372 (N), HQ266631 (P) } \neq \\
\text { HQ266613 (M) } \ddagger \text {, FJ465390 (G). }\end{array}$ \\
\hline LBV† & Durban, South Africa & $\begin{array}{l}\text { Frugivorous bat } \\
\text { (Epomophorus wahlbergi) }\end{array}$ & 2008 & LBVSA2008 & $\begin{array}{l}\mathrm{HM} 179509(\mathrm{~N}) \ddagger, \mathrm{HQ} 266634(\mathrm{P}) \\
\mathrm{HQ} 266612(\mathrm{M}) \ddagger\end{array}$ \\
\hline LBV & Amanzimtoti, South Africa & $\begin{array}{l}\text { Frugivorous bat } \\
\text { (Epomophorus wahlbergi) }\end{array}$ & 2006 & LBVSA2006 & $\begin{array}{l}\text { EF547452 (N), EF547414 (P), } \\
\text { EF547435 (M), EF547422 (G). }\end{array}$ \\
\hline LBV† & $\begin{array}{l}\text { Exported to France from an unknown } \\
\text { African origin }\end{array}$ & $\begin{array}{l}\text { Frugivorous bat } \\
\text { (Rousettus aegyptiacus) }\end{array}$ & 1999 & LBVAFR1999 & $\begin{array}{l}\text { EF547447 (N), EF547418 (P), } \\
\text { EF547445 (M), EF547432 (G). }\end{array}$ \\
\hline LBV $\dagger$ & Lagos Island, Nigeria & $\begin{array}{l}\text { Frugivorous bat } \\
\text { (Eidolon helvum) }\end{array}$ & 1956 & LBVNIG1956 & $\begin{array}{l}\text { EF547459 (N), EF547407 (P), } \\
\text { EF547444 (M), EF547431 (G). }\end{array}$ \\
\hline LBV† & Durban, South Africa & $\begin{array}{l}\text { Frugivorous bat } \\
\text { (Epomophorus wahlbergi) }\end{array}$ & 2004 & LagSA2004 & $\begin{array}{l}\text { EF547458 (N), EF547415 (P), } \\
\text { EF547440 (M), EF547428 (G). }\end{array}$ \\
\hline LBV $\dagger$ & Westville, South Africa & $\begin{array}{l}\text { Slender mongoose } \\
\text { (Atilax paludinosus) }\end{array}$ & 2004 & Mongoose2004 & $\begin{array}{l}\text { EF547453 (N), EF547409 (P), } \\
\text { EF547438 (M), EF547423 (G). }\end{array}$ \\
\hline MOKV† & Bulawayo, Zimbabwe & $\begin{array}{l}\text { Cat } \\
\text { (Felis domesticus) }\end{array}$ & 1981 & 12341 & $\begin{array}{l}\text { FJ465417 (N), GQ861350 (P) } \$ \\
\text { GQ472991 (M) } \$, G Q 473003(\mathrm{G})\end{array}$ \\
\hline MOKV & East London, South Africa & $\begin{array}{l}\text { Cat } \\
\text { (Felis domesticus) }\end{array}$ & 1995 & $543 / 95$ & $\begin{array}{l}\text { FJ465415 (N), GQ500116 (P) } \ddagger \\
\text { GQ472992(M) } \neq, G Q 500110(\mathrm{G}) \ddagger .\end{array}$ \\
\hline MOKV† & Pinetown, South Africa & $\begin{array}{l}\text { Cat } \\
\text { (Felis domesticus) }\end{array}$ & 1997 & 252/97 & $\begin{array}{l}\text { Unpublished (N) AF369376 (P), } \\
\text { GQ472997 (M) } \$ \text {, GQ500112 (G) }\end{array}$ \\
\hline MOKV & East London, South Africa & $\begin{array}{l}\text { Cat } \\
\text { (Felis domesticus) }\end{array}$ & 2006 & $173 / 06$ & $\begin{array}{l}\text { FJ465412 (N), GQ861351 (P) } \div \\
\text { GQ472999 (M) } \neq, H Q 266624(\mathrm{G}) \ddagger\end{array}$ \\
\hline MOKV & Zimbabwe & $\begin{array}{l}\text { Cat } \\
\text { (Felis domesticus) }\end{array}$ & 1981 & - & S59447 \\
\hline DUVV $\dagger$ & Pilanesberg, South Africa & $\begin{array}{l}\text { Human } \\
\text { (Homo sapiens) }\end{array}$ & 2006 & DUVVSA2006 & EU623444 \\
\hline DUVV & Louis Trichardt, South Africa & $\begin{array}{l}\text { Insectivorous bat } \\
\text { (Unidentified) }\end{array}$ & 1981 & DUVVSA1981 & $\begin{array}{l}\text { EU623438 (N), EU623439 (P), } \\
\text { EU623441 (M), EU623443 (G). }\end{array}$ \\
\hline DUVV & Bela Bela, South Africa & $\begin{array}{l}\text { Human } \\
\text { (Homo sapiens) }\end{array}$ & 1970 & DUVVSA1970 & $\begin{array}{l}\text { EU623437 (N), EU623436 (P), } \\
\text { EU623440 (M), EU623442 (G). }\end{array}$ \\
\hline
\end{tabular}

RABV, Rabies virus; LBV, Lagos bat virus; MOKV, Mokola virus; DUVV, Duvenhage virus.

$\dagger$, Isolates used in experimental infections in mice.

* Sequences determined in this study.

$\$$, The groups for RABV (canid and mongoose variants) refer to phylogenetic grouping as indicated in Nel, L.H., Sabeta, C.T., Von Teichman, B., Jaftha, J.B., Rupprecht, C.E. \& Bingham, J., 2005, 'Mongoose rabies in southern Africa: A re-evaluation based on molecular epidemiology', Virus Research 109, 165-173 and Cohen, C., Sartorius, B., Sabeta, C., Zulu, G., Paweska, J., Mogoswane, M. et al., 2007, 'Epidemiology and molecular virus characterization of reemerging rabies, South Africa', Emerging Infectious Diseases 13, $1879-1886$.

RNA by Taqman real-time PCR (Coertse et al. 2010). Integrity of the isolated RNA was also tested using real-time PCR (Nakahata et al. 2006).

\section{Rapid fluorescent focus inhibition test}

Virus neutralising antibodies (VNA) were determined by a modification of the rapid fluorescent focus inhibition test (RFFIT) (Kuzmin et al. 2008). The following challenge viruses were used: Challenge Virus Standard (CVS) strain for both RABV (canid and mongoose variants), LBVSA2006 for all isolates of LBV except LBVAFR1999, LBVAFR1999 for LBVAFR1999, MOKV252/97 for all MOKV isolates and DUVVSA2006 for DUVVSA2006. The 50\% end point neutralising titres were calculated according to the method of Reed and Muench (1983). 


\section{Ethical considerations}

Ethical approval (15/04/P001) for all procedures involving the use of mice was granted by the Onderstepoort Veterinary Institute Ethical Committee, Pretoria, South Africa.

\section{Results}

\section{Comparison of pathogenic domains The nucleoprotein}

An alignment of proposed pathogenic domains on the N gene is shown in Figure 1. Phe 273 and Tyr 394 were shown to be important for evasion of retinoic acid-inducible gene I mediated innate immunity and pathogenicity (Masatania et al. 2011). It was found that Phe 273 was conserved in all isolates analyzed in this study. Tyr 394 was only conserved for RABV isolates with the exception of one representative RABV isolate (RC-HL) which had His in this position. All isolates of LBV, MOKV and DUVV had Tyr substituted by Phe.

\section{The phosphoprotein}

An alignment of the partial $\mathrm{P}$ protein (aa140-aa150) indicating the region previously implicated in retrograde intracellular transport of the virus to the CNS is indicated in Figure 2. The four residues on position 144-148 (K/RXTQT, with $\mathrm{X}$ representing any amino acid) important for $\mathrm{P}$ protein binding to the LC8 dynein light chain were conserved for all RABV (both variants), LBV and DUVV isolates compared in this study. The RC-HL isolate of RABV had a substitution of Thr 148 to Ile. MOKV isolates had substitutions at positions 144 and 146 of the LC8 dynein light chain binding motif; Arg/Lys 144 and Thr 146 were both replaced by Ile with the exception of isolate MOKV252/97 where Val instead of Ile substituted the Arg/Lys 144.

\section{The matrix protein}

A partial alignment that encompasses domains on the $\mathrm{M}$ gene previously implicated in pathogenicity is shown in Figure 3.

Firstly, the ASAP motif at position 22-25 was reported to be important for the pathogenicity of a related rhabdovirus, vesicular stomatitis virus (Irie et al. 2007). The motif was conserved for HEP-Flury, RC-HL, MOKV isolates and LBVAFR1999, whilst for other RABV isolates and DUVV Ala was substituted by Val and by Pro in LBV isolates.

Secondly, a motif at position 35-38 (PPEY) was shown to be necessary for efficient virion release and pathogenicity (Wirblich et al. 2008). The PPEY motif was conserved in all the lyssavirus isolates. The VPL motif (amino acid 39-41) which overlaps the PPEY, PPEYVPL, was indicated to be important in RABV budding, though not as important as the PPEY (Wirblich et al. 2008). The VPL motif was also conserved except for the SHBRV-18 isolate of RABV which had a substitution of Val to Ile in position 39.

Thirdly, Lys 77 and Asp 81 were shown to be important in disruption of the mitochondrion and induction of apoptosis

\begin{tabular}{|c|c|c|}
\hline & ח & $1+\cdots+\cdots$ \\
\hline & 270 & 390 \\
\hline Nishigahara & RRMFEPGQETA & DDED|YESGEAR \\
\hline \multirow{2}{*}{$\begin{array}{l}\text { ERA } \\
\text { HEP-Flury }\end{array}$} & 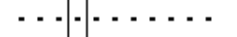 & $\ldots{ }_{1}$ \\
\hline & & $\ldots \mathrm{T}$. \\
\hline LEP-Flury & $\cdots$ & $\cdots \mathrm{T}$. \\
\hline PV & $\cdots$ & $\cdots$. \\
\hline RC-HL & $\cdots$ & $\cdots$ H. \\
\hline $\begin{array}{l}\text { SHBRV-18 } \\
567 / 04]\end{array}$ & $\cdots$ & $\ldots$. . \\
\hline $31 / 05$ & $\cdots$ & $\cdots \mathrm{T}$ \\
\hline \begin{tabular}{l|l}
$262 / 06$ & RABV (canid \\
$479 / 96$ & variant)
\end{tabular} & & A.T. \\
\hline \multirow{2}{*}{$\begin{array}{l}819 / 05 \\
113 / 91\end{array}$} & $\cdots$ & $\ldots \mathrm{T}$ \\
\hline & $\ldots \ldots s$ & $\cdots \mathrm{T}$ \\
\hline 364/96 RABV & $\because$ & $\begin{array}{l}-1 \mathrm{~T} \\
\cdots \mathrm{T}\end{array}$ \\
\hline \begin{tabular}{l|l}
22107 & (mongoose \\
$669 / 90$ & variant)
\end{tabular} & & .T. \\
\hline $767 / 95]$ & $\cdots$ & $\cdots \cdots$ \\
\hline $\begin{array}{l}\text { LagsA2004 } \\
\text { LBVSA2006 }\end{array}$ & $\begin{array}{l}\text { K.. } \\
\text { K. }\end{array}$ & 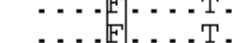 \\
\hline LBVSA2008 & K.. & $\ldots \ldots$ \\
\hline LBVNIG1956 LBV & $\mathrm{K}$. & $\ldots F$ \\
\hline LBVMong2004 & $\mathrm{K}$. & $\ldots F$ \\
\hline LBVAFR1999 ] & $\mathrm{K}$. & $\ldots E E \mid$. \\
\hline 12341 & $\mathrm{~K}$. & 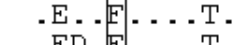 \\
\hline $543 / 95$ & $\mathrm{~K} \cdot \cdot$ & -ED $-F \mid \cdots$ T. \\
\hline $\begin{array}{l}173 / 06 \\
252 / 97\end{array}$ & & $\begin{array}{c}-E D \\
F\end{array}$ \\
\hline DUVVSA2006] & K.. & $\ldots$ EDT. \\
\hline \begin{tabular}{l|l} 
DUVVA1981 & DUW
\end{tabular} & & $\ldots E \mid \ldots D T$. \\
\hline DUVVSA1970] & $\cdots \cdots$ & $\ldots$ E. . . DT \\
\hline
\end{tabular}

GenBank accession numbers are indicated in Table 1. The boxes indicate the regions implicated in pathogenicity.

FIGURE 1: Multiple alignments of the partial nucleoprotein amino acids sequences of representative lyssavirus isolates. These regions were previously implicated in evasion of innate immunity and pathogenicity (aa273 and 394).

\begin{tabular}{|c|c|}
\hline 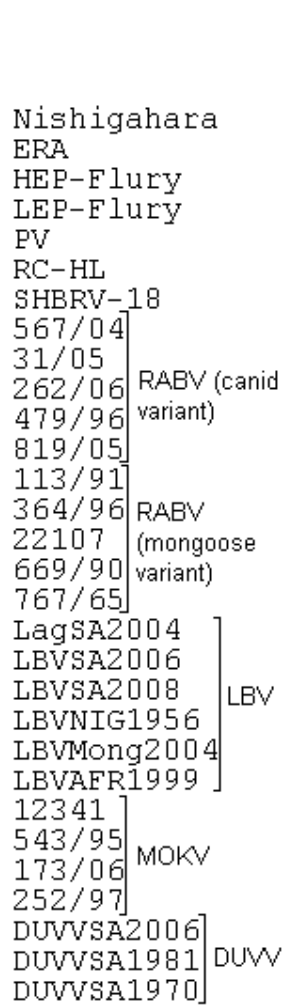 & 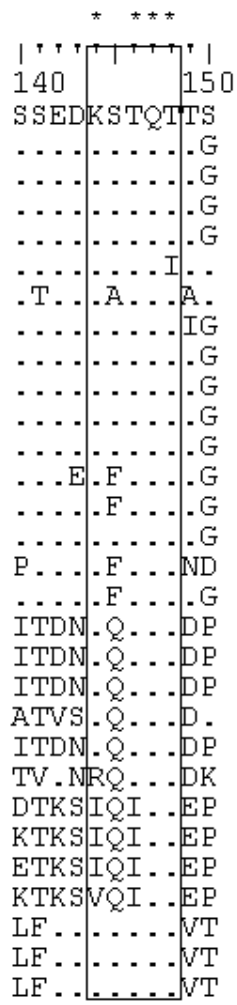 \\
\hline
\end{tabular}

GenBank accession numbers are indicated in Table 1.

FIGURE 2: Multiple alignments of partial phosphoprotein amino acids sequences of representative lyssavirus isolates. The box indicates the region important for binding to the LC8 dynein light chain with amino acids important for binding indicated by*. 
(Gholami et al. 2008). All RABV (canid and mongoose variants) isolates had Arg 77 and Glu 81. The ERA isolate of RABV, all isolates of LBV and MOKV had Arg 77 to Lys substitution. LBV LBVSA2008, LBVSA2006, LBVMong2004 and LBVSA2004 and MOKV 252/97 had a Ser at position 81 whilst the other isolates of LBV LBVAFR1999 and LBVNig1956 and MOKV 12341, 543/95 and 173/06 had an Asn at this position. DUVV isolates had Arg 77 as with RABV isolates, but the Glu 81 was replaced by Gly.

Lastly, Mita et al. (2008) showed that mutation of Val to Ala at position 95 results in increased apoptosis. Val 95 was conserved amongst all the lyssavirus isolates compared except for the RABV mongoose variant; 22107 and LBVAFR1999 isolates, which had a substitution to Ile.

\section{The glycoprotein}

An alignment of the partial $G$ proteins of representative lyssavirus isolates is shown in Figure 4, with domains previously implicated in pathogenicity indicated. Most of the amino acids on the $G$ protein that have been indicated to be important for pathogenicity were conserved for RABV (canid and mongoose variants) isolates in this study.

Firstly, the peptide fragment between amino acid 189 and 214 has been indicated to be important for RABV binding to the nicotinic acetylcholine receptor (Lentz et al. 1984). Within this fragment, substitution of Asn 194 with Lys was reported to result in increased pathogenicity (Faber et al. 2005) whilst mutation of Arg/Lys 198 resulted in reduced pathogenicity (Lentz et al. 1984). Asn 194 was conserved for all RABV (both variants) except for the HEPFlury isolate, which had a substitution of Asn 194 to His. Arg/Lys 198 was conserved for all isolates in this study. Substitutions were observed on this nicotinic acetylcholine receptor fragment for RABV (canid and mongoose variants) but there were more variations within LBV, MOKV and DUVV isolates than in RABV isolates.

Secondly, Ala 242, Asp 255 and Ile 268 were reported to be important for the pathogenicity of the Nishigahara strain with Ile 268 being the most important residue (Takayama-Ito et al. 2006). The RABV isolates SHBRV-18 and RC-HL had a substitution of Ala 242 to Ser. Asp 255 from RABV isolates PV, LEP-Flury and HEP-Flury was substituted by Gly and by Asn in RC-HL. The RC-HL strain also had Ile 268 replaced by Leu. Ala 242 was substituted by Ser in LBV, MOKV and DUVV whilst Asp 255 was substituted by Asn in MOKV and all LBV isolates except for LBVAFR1999, which had this amino acid conserved, as with RABV and DUVV. All LBV, MOKV and DUVV isolates had Ile 268 conserved. This was with the exception of LBVNig1956, which had Val in that position.

Thirdly, mutation of Arg/Lys 333 on the G protein was reported to result in non-pathogenic strains when inoculated i.m. (Badrane et al. 2001; Dietzschold et al. 1983). Unlike all RABV species analysed in this study, HEP-Flury had Gln at position 333 instead of Arg/Lys. All LBV isolates except for LBVAFR1999 had Arg 330 substituted by Leu. LBVAFR1999, MOKV and DUVV had Lys 330 conserved. Arg/Lys 333 was substituted by Asp in all LBV and MOKV isolates.

Lastly, Phe 318 and His 352 on the RABV G protein have been shown to be important for binding to the p75 neurotrophin receptor (p75NTR) (Langevin et al. 2002). All LBV and DUVV had Phe 318 substituted with Ile; this was with the exception of LBV isolates LBVNig1956 and LBVAFR1999 which had Leu as with all MOKV isolates. His 352 was substituted with Val in all LBV isolates except for LBVAFR1999, which had Met, as with all MOKV isolates, whilst DUVV had Tyr on this position.

A MOKV isolate (MokZim) reported by Badrane et al. (2001) to be non-pathogenic when inoculated i.m. had identical pathogenic domains on the $G$ protein, as with MOKV (12341), and differed from other MOKV isolates with a single substitution of Lys 198 to Arg.

\section{Pathogenicity of representative African lyssaviruses in mice}

\section{Mortality of mice inoculated intramuscular with a dose of $10^{5} \mathrm{TCID}_{50}$}

All isolates investigated in this study, except for LBV (LBVNig1956) were lethal to mice through the i.m. route. All mice that died exhibited symptoms typical of lyssavirus infection. This included walking in circles, hind leg paralysis, loss of weight and ruffled fur. Inoculation with different isolates did not result in differences in symptoms. All brains collected from mice that died or were euthanised during development of symptoms tested positive with FAT. The control group and those that survived (euthanised at the end of the experiment) tested negative. Mortality ranged from $0 \%$ to $75 \%$ with an incubation period from 7 to 29 days whilst the mean incubation period ranged from 9.25 to 26 days (Figure 5 and Table 2). LBV (LBVSA2008) had the highest mean incubation period compared to other lyssavirus isolates analysed in this study. Mice inoculated with MOKV had the highest percentage mortality $(75 \%)$, followed by RABV (mongoose variant) (67\%), LBV and DUVV (50\%), and then RABV (canid variant) (33\%).

\section{Effect of inoculation dose on mortality of mice}

Inoculation at a higher dose $\left(10^{8} \mathrm{TCID}_{50}\right)$ with lineage A (LBVAFR1999) and C (LBVMong2004) LBV isolates showed a difference in mortality between these lineages. Lineage A had higher percentage mortality and lower mean incubation period than lineage $\mathrm{C}$ (Table 2).

\section{Comparison of the pathogenicity of representative phylogroup II lyssaviruses}

Comparison of MOKV and LBV pathogenicity at a higher dose $\left(10^{7} \mathrm{TCID}_{50}\right)$ indicated MOKV $(252 / 97)$ to be more 


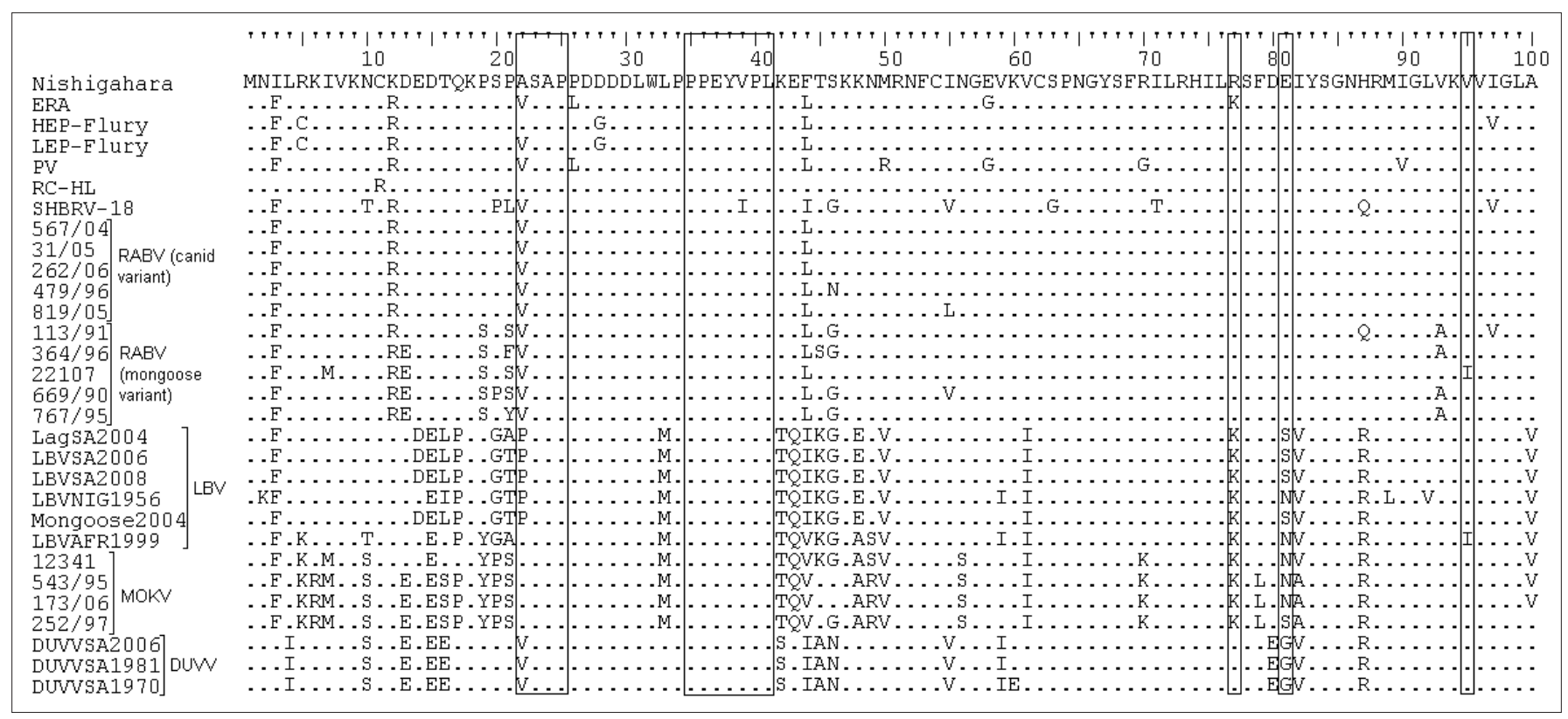

GenBank accession numbers are indicated in Table 1.

FIGURE 3: Multiple alignments of partial matrix protein amino acids sequences (aa1-aa100) of representative lyssavirus isolates. The boxes indicate regions implicated in pathogenicity.

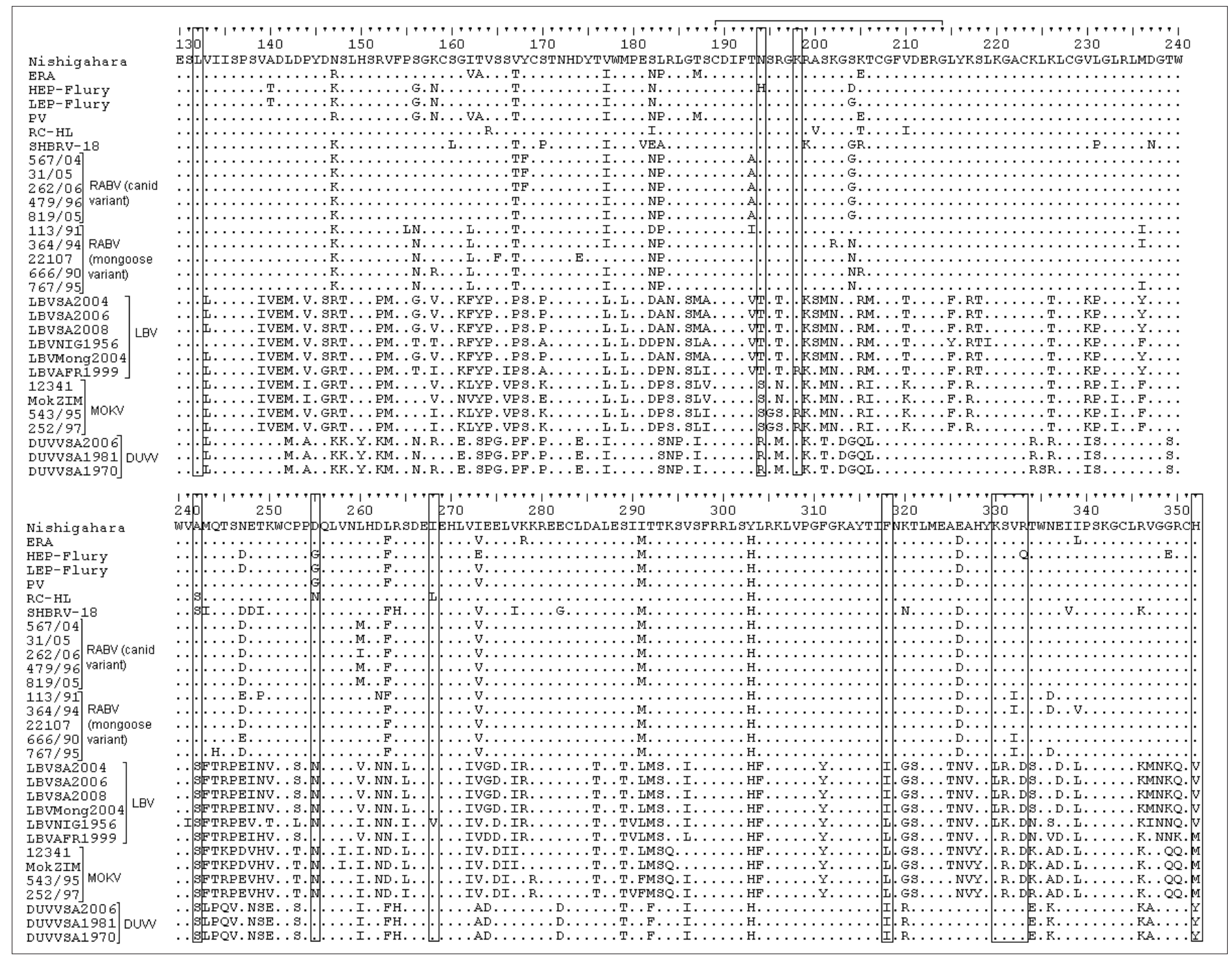

GenBank accession numbers are indicated in Table 1.

FIGURE 4: Multiple alignments of the partial glycoprotein amino acids sequences (aa130-aa352) of representative lyssavirus isolates. The boxes indicate amino acids previously shown to be important for pathogenicity. 
lethal than LBV (LBVSA2004). The trend was the same at inoculation of these species at $10^{5} \mathrm{TCID}_{50}$ (Table 2).

\section{Comparison of the pathogenicity of cell culture and original bat brain material of LBV (LBVSA2008)}

Inoculation with $10 \%$ suspension of the original bat brain material resulted in an increase in percentage mortality and a decrease in mean incubation period as compared to inoculation with a dose of $10^{5} \mathrm{TCID}_{50}$. However, no mortalities were observed when a dose of $10^{3} \mathrm{TCID}_{50}$ was used (Table 2).

\section{Viral RNA concentration in organs and blood}

A Taqman real-time PCR (Coertse et al. 2010) was used to determine the presence and viral RNA concentration from the brains, salivary glands and blood of mice that succumbed to African lyssavirus infection. Salivary glands and blood of all mice tested were negative. The RNA in these negative samples was intact based on amplification of the 18S rRNA (data not shown). Amplification of the 18S rRNA from the salivary glands to comparable levels as the positive brain samples rules out the possibility of false negatives from the salivary glands. There was no viral RNA detected in the brains of the control group. There was variation in viral RNA concentration in the brains of mice inoculated with different lyssavirus species as well as those inoculated with isolates of the same species. The standard deviations were generally large, ranging from 43.71 mean copy number/ng of RNA for LBV to 113698 mean copy number/ng of RNA for RABV (mongoose variant) when mice where inoculated at $10^{5} \mathrm{TCID}_{50}$ indicating that there were large differences in viral RNA concentration in the brains of mice inoculated with the same virus isolate (Table 2). Since a small portion of the mixed whole brain was used for RNA isolation, the difference in viral RNA concentration from mice inoculated with the same dose of the same virus strain could be due to the differences in virus distribution during mixing of the brain material.

\section{Correlation between pathogenic domains and mortality of mice}

The relationships between the integrity of pathogenic domains and incubation time and mortality in mice are shown in Table 3. It can be assumed that the sequences used to identify differences in pathogenic domains were the same as the sequences of the inocula used for experimental infection of mice, since only a few passages were carried out from the sequenced material to obtain the titre used for experimental infection. Comparison of pathogenic domains on the nucleoprotein, phosphoprotein, matrix and glycoprotein showed that substitutions of particular amino acids associated with such domains are not consistent between isolates of the same species. This was with the exception of isolates that were used as representatives of RABV (canid and mongoose variants) and DUVV isolates which had the same amino acids on pathogenic domains. The conservation of most of the known pathogenic domains

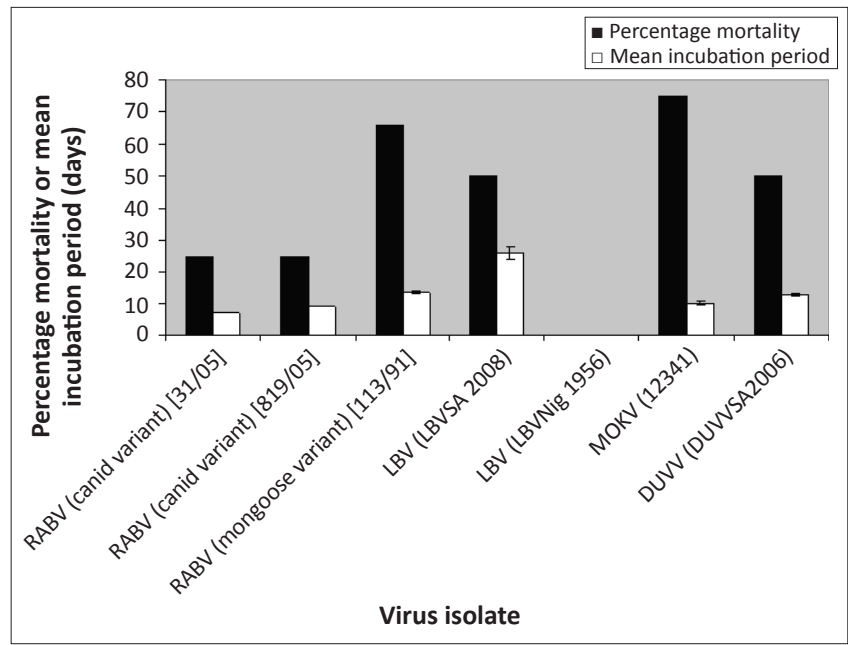

RABV, Rabies virus; LBV, Lagos bat virus; MOKV, Mokola virus; DUVV, Duvenhage virus. Standard deviations are indicated. LBVNig1956 had 0\% mortality. Standard deviations for RABV (canid variant) isolates $31 / 05$ and $819 / 05$ were not determined because only one mouse succumbed in each of these groups.

FIGURE 5: Percentage mortality and mean incubation period of mice after intramuscular inoculation with a $10^{5} \mathrm{TCID}_{50}$ of different lyssavirus isolates.

TABLE 2: Summary of experimental infections of mice with lyssavirus isolates.

\begin{tabular}{|c|c|c|c|c|c|}
\hline \multirow[t]{2}{*}{ Inoculation dose } & \multirow[t]{2}{*}{ Virus isolate } & \multirow[t]{2}{*}{$\begin{array}{l}\text { Mean copy number/ng of } \\
\text { RNA and s.d. }\end{array}$} & \multicolumn{2}{|c|}{$\begin{array}{l}\text { Mean incubation period, s.d. and range of } \\
\text { incubation periods (days) }\end{array}$} & \multirow{2}{*}{$\begin{array}{l}\text { Number of mice that } \\
\text { died per group of mice } \\
\text { inoculated by the isolate }\end{array}$} \\
\hline & & & Mean and s.d. & Range & \\
\hline Inoculation with $10^{3} \mathrm{TCID}_{50}$ & LBVSA2008 (LBV) & ND & 0 & - & $0 / 4$ \\
\hline \multirow[t]{7}{*}{ Inoculation with $10^{5} \mathrm{TCID}_{50}$} & $819 / 05$ (RABV [canid variant]) & $185979.97 \pm N / A$ & $7 \pm N A$ & 7 & $1 / 4$ \\
\hline & 31/05 (RABV [canid variant]) & $16882.93 \pm N / A$ & $9 \pm N A$ & 9 & $1 / 4$ \\
\hline & $113 / 91$ (RABV [mongoose variant]) & $132135.54 \pm 113698$ & $13.5 \pm 0.707107$ & $13-14$ & $2 / 3$ \\
\hline & LBVSA2008 (LBV) & $57.65 \pm 43.71$ & $26 \pm 4.242$ & $23-29$ & $2 / 4$ \\
\hline & LBVNig1956 (LBV) & ND & 0 & - & $0 / 4$ \\
\hline & 12341 (MOKV) & $977.25 \pm 748.5912$ & $10 \pm 1$ & $9-11$ & $3 / 4$ \\
\hline & DUVVSA2006 (DUVV) & $58.11 \pm 51.60465$ & $12.5 \pm 0.707$ & $12-13$ & $2 / 4$ \\
\hline \multirow[t]{2}{*}{ Inoculation with $10^{7} \mathrm{TCID}_{50}$} & LBVSA2004 (LBV) & $5746.45 \pm 8706.089$ & $9.33 \pm 3.214$ & $7-13$ & $3 / 5$ \\
\hline & 252/97 (MOKV) & $54719.25 \pm 62601.73$ & $9.25 \pm 3.304$ & $7-14$ & $4 / 5$ \\
\hline \multirow[t]{2}{*}{ Inoculation with $10^{8} \mathrm{TCID}_{50}$} & LBVMong2004 (LBV) & $1724.1 \pm 265.6247$ & $8.5 \pm 2.121$ & $7-10$ & $2 / 5$ \\
\hline & LBVAFR1999 (LBV) & $53867.98 \pm 39393.19$ & $7 \pm 0$ & 7 & $4 / 5$ \\
\hline $\begin{array}{l}\text { Inoculation with } 10 \% \\
\text { suspension of original bat } \\
\text { brain material }\end{array}$ & LBVSA2008 (LBV) & $14371.31 \pm 17416.9$ & $15.75 \pm 3.5$ & $14-21$ & $4 / 5$ \\
\hline
\end{tabular}

LBV, Lagos bat virus; RABV, Rabies virus; MOKV, Mokola virus; DUVV, Duvenhage virus; ND, indicates not done; N/A, not applicable because only one mouse died; s.d., standard deviation. 
for phylogroup I (RABV [canid and mongoose variants] and DUVV) as compared to phylogroup II lyssaviruses (LBV and MOKV) did not correlate with increased overall pathogenicity observed in mice. MOKV demonstrated high percentage mortality compared to RABV and DUVV when inoculated at the same viral dose despite having most of the known pathogenic domains mutated. Generally there was no clear correlation between substitutions on pathogenic domains and mortality.

\section{Serological response of mice after inoculation with different lyssavirus isolates}

The VNA titre was not converted to international units as there are no available reference sera for $\mathrm{LBV}, \mathrm{MOKV}$ or DUVV and therefore results were only reported as the titre at which neutralisation occurred. There were detectable VNAs in all mice on day 7, with the exception of three mice that were inoculated with RABV (mongoose variant) (Table 4). There was no clear difference in VNA titre between mice that survived and those that died (day 7 and 14). VNA titre increased on day 14 and a peak was reached on day 28 , followed by a drop on days 42, 50 and 60 . However, the titre was still above 200. All the mice inoculated with RABV (mongoose variant) maintained low VNA titres throughout the experiment and one animal in this group survived until the end of the experiment. Since only 3 mice were inoculated by the RABV (mongoose variant) of which 2 died at day 13 and 14 it could not be determined whether the VNA would be comparable with other lyssavirus species at a later stage. The low blood volumes collected by ocular bleeds did not allow the neutralisation tests to be repeated using a RABV (mongoose variant) as a challenge virus to determine the possibility that the challenge virus was the reason for the low VNA titre observed.

\section{Discussion}

\section{Pathogenicity of different African lyssavirus isolates inoculated intramuscular in mice}

Lyssavirus isolates in this study represent a larger diversity of African lyssavirus isolates than in previous studies
(Badrane et al. 2001; Kemp et al. 1973; Kuzmin et al. 2008; Markotter et al. 2009). All lyssavirus isolates except one LBV (LBVNig1956) isolate were lethal to mice through the i.m. route of infection. Differences in pathogenicity within lyssavirus species were observed in LBV and RABV (canid and mongoose variants) isolates. This was in agreement with our previous recognition of this phenomenon between LBV isolates (Markotter et al. 2009). The difference in pathogenicity between isolates of the same species indicated the need to compare a number of isolates within a species when evaluating the pathogenicity. The pathogenicity of phylogroup II lyssaviruses were found to be in agreement with results from other recent studies (Kuzmin et al. 2008; Markotter et al. 2009) and those from one early study (Kemp et al. 1973), all of which indicated that these lyssaviruses can be lethal (at relatively low doses) through the i.m. route. This finding was in contradiction to conclusions from Badrane et al. (2001). However, the only LBV isolate that was not lethal in the present study, was the isolate used by Badrane et al. (2001), LBVNIG1956. MOKV has been isolated from domestic mammals such as canines and cats (Sabeta et al. 2010), whilst LBV has been isolated from a mongoose, bats and canines (Markotter et al. 2006a; Markotter et al. 2006b). If phylogroup II lyssavirus isolates were only lethal via the i.c. route, there would be less isolation of these viruses in nature, since a bite by a rabid animal would have to penetrate the skull. Therefore, the epidemiology of these viruses further supports the observation that LBV and MOKV can be lethal when inoculated i.m. in animals.

In this study, MOKV isolates were more pathogenic than isolates used as representatives of phylogroup I lyssaviruses (RABV [canid and mongoose variants] and DUVV). This does not necessarily mean that MOKV isolates studied here are the more pathogenic lyssaviruses but it does demonstrate that the pathogenicity of MOKV was previously underestimated. It also showed that different isolates within a species exhibit different pathogenicity profiles. When inoculation dose was increased, isolates that had high percentage mortality also

TABLE 3: Comparison of amino acids of pathogenic domains on lyssavirus genomes. The mean incubation time and percentage mortality observed in mice are also indicated.

\begin{tabular}{|c|c|c|c|c|c|c|c|c|c|c|c|c|c|c|c|}
\hline \multirow[t]{2}{*}{ Lyssavirus isolate and titer } & \multirow{2}{*}{$\begin{array}{l}\text { Phosphoprotein } \\
\text { (K/RXTQT) }\end{array}$} & \multicolumn{3}{|c|}{ Matrix protein } & \multicolumn{9}{|c|}{ Glycoprotein } & \multirow{2}{*}{$\begin{array}{l}\text { Mean } \\
\text { incubation } \\
\text { period }\end{array}$} & \multirow{2}{*}{$\begin{array}{l}\% \\
\text { Mortality }\end{array}$} \\
\hline & & R77 & E81 & v95 & N194 & K198 & A242 & D255 & 1268 & F318 & K/R330 & K/R333 & H352 & & \\
\hline $819 / 05\left(10^{5} \mathrm{TCID}_{50}\right)$ & KSTQT & $v$ & V & V & V & $v$ & V & V & $\checkmark$ & $\checkmark$ & $v$ & V & $v$ & 7 & 25 \\
\hline $31 / 05\left(10^{5} \mathrm{TCID}_{50}\right)$ & KSTQT & $\checkmark$ & v & v & v & $v$ & v & v & v & $v$ & $v$ & $\checkmark$ & $v$ & 9 & 25 \\
\hline $113 / 91\left(10^{5} \mathrm{TCID}_{50}\right)$ & KSTQT & $\checkmark$ & v & $v$ & v & $v$ & $v$ & $v$ & $v$ & $v$ & $v$ & v & $v$ & 13.5 & 67 \\
\hline LBVSA2008 $\left(10^{3} \mathrm{TCID}_{50}\right)$ & КQTQT & K & $\mathrm{S}$ & v & $\mathrm{T}$ & $v$ & $\mathrm{~S}$ & $\mathrm{~N}$ & v & 1 & L & D & V & 0 & 0 \\
\hline LBVSA2008 $\left(10^{5} \mathrm{TCID}_{50}\right)$ & кQTQT & K & $S$ & $\checkmark$ & $\mathrm{T}$ & $v$ & $S$ & $\mathrm{~N}$ & v & 1 & L & $\mathrm{D}$ & V & 26 & 50 \\
\hline LBVNig1956 $\left(10^{5} \mathrm{TCID}_{50}\right)$ & KQTQT & K & $\mathrm{N}$ & $v$ & $\mathrm{~T}$ & v & $\mathrm{S}$ & $\mathrm{N}$ & V & L & L & D & V & 0 & 0 \\
\hline LBVAFR1999 $\left(10^{8} \mathrm{TCID}_{50}\right)$ & RQTQT & K & $\mathrm{N}$ & 1 & $\mathrm{~T}$ & $v$ & $\mathrm{~S}$ & $v$ & $v$ & L & v & D & M & 7 & 80 \\
\hline LBVSA2004 $\left(10^{7} \mathrm{TCID}_{50}\right)$ & KQTQT & K & $\mathrm{S}$ & v & $\mathrm{T}$ & v & $\mathrm{S}$ & $\mathrm{N}$ & $v$ & 1 & L & D & V & 9.33 & 60 \\
\hline LBVMong2004 $\left(10^{8} \mathrm{TCID}_{50}\right)$ & KQTQT & K & $\mathrm{S}$ & $v$ & $\mathrm{~T}$ & $\mathrm{R}$ & $S$ & $\mathrm{~N}$ & $v$ & 1 & L & D & V & 8.5 & 40 \\
\hline $12341\left(10^{5} \mathrm{TCID}_{50}\right)$ & IQIQT & K & $\mathrm{N}$ & v & $S$ & v & $S$ & $\mathrm{~N}$ & $v$ & L & $v$ & D & M & 10 & 75 \\
\hline $252 / 97\left(10^{7} \mathrm{TCID}_{50}\right)$ & IQIQT & K & $\mathrm{S}$ & $v$ & $S$ & $\mathrm{R}$ & $\mathrm{S}$ & $\mathrm{N}$ & $v$ & L & $v$ & D & M & 9.25 & 80 \\
\hline
\end{tabular}

$V$, indicates conserved; $X$, any amino acid; $K$, Lysine; S, Serine; T, Threonine; $Q$, Glutamine; R, Arginine; I, Isoleucine; N, Asparagine; G, Glycine; V, Valine; L, Leucine; D, Aspartic acid; E, Glutamic acid; $Y$, Tyrosine; M, Methionine; A, Alanine; F, Phenylalanine; H, Histidine. 
TABLE 4: Virus neutralising antibodies titre in mice inoculated with different lyssavirus isolates as determined by the Rapid fluorescent focus inhibition assay.

\begin{tabular}{|c|c|c|c|c|c|c|c|c|c|c|}
\hline \multirow[t]{2}{*}{ Inoculation dose } & \multirow[t]{2}{*}{ Lyssavirus species } & \multirow[t]{2}{*}{ Virus isolate } & \multirow[t]{2}{*}{ Died/Survived } & \multirow[t]{2}{*}{ Day $\dagger$} & \multicolumn{6}{|c|}{ Virus neutralising antibodies } \\
\hline & & & & & Day 7 & Day 14 & Day 28 & Day 42 & Day 50 & Day 60 \\
\hline \multirow{17}{*}{$\begin{array}{l}\text { Inoculation with } \\
10^{5} \mathrm{TCID}_{50}\end{array}$} & \multirow{7}{*}{$\begin{array}{l}\text { RABV } \\
\text { (canid variant) }\end{array}$} & 31/05 (mouse 1) & Died & 9 & 35 & - & - & - & - & - \\
\hline & & 31/05 (mouse 2) & Survived & - & 18 & 798 & - & - & 769 & - \\
\hline & & 31/05 (mouse 3) & Survived & - & 76 & 564 & - & - & 1581 & \\
\hline & & 31/05 (mouse 4) & Survived & - & 32 & 562 & - & - & 630 & - \\
\hline & & $819 / 05$ (mouse 1 ) & Died & 7 & 84 & - & - & - & - & - \\
\hline & & $819 / 05$ (mouse 2) & Survived & - & 25 & 225 & - & - & - & - \\
\hline & & 819/05 (mouse 4) & Survived & - & 29 & 457 & - & - & 1097 & - \\
\hline & \multirow{3}{*}{$\begin{array}{l}\text { RABV } \\
\text { (mongoose variant) }\end{array}$} & 113/91 (mouse 1) & Died & 14 & 0 & 12 & - & - & - & - \\
\hline & & 113/91 (mouse 2) & Survived & - & 0 & 15 & - & - & 39 & - \\
\hline & & 113/91 (mouse 3) & Died & 13 & 0 & - & - & - & - & - \\
\hline & \multirow[t]{3}{*}{ MOKV } & 12341 (mouse 1) & Survived & - & 54 & 487 & 1581 & - & 423 & - \\
\hline & & 12341 (mouse 2) & Died & 9 & - & - & - & - & - & - \\
\hline & & 12341 (mouse 3) & Died & 10 & 25 & - & - & - & - & - \\
\hline & \multirow[t]{4}{*}{ DUVV } & DUVVSA2006 (mouse 1) & Survived & - & 34 & 520 & - & - & 673 & - \\
\hline & & DUVVSA2006 (mouse 2) & Died & 13 & 25 & - & - & - & - & - \\
\hline & & DUVVSA2006 (mouse 3) & Survived & - & 21 & 564 & - & - & 624 & - \\
\hline & & DUVVSA2006 (mouse 4) & Died & 12 & - & - & - & - & - & - \\
\hline \multirow{10}{*}{$\begin{array}{l}\text { Inoculation with } \\
10^{7} \mathrm{TCID}_{50}\end{array}$} & \multirow[t]{5}{*}{ LBV } & LBVSA2004 (mouse 1) & Survived & - & 25 & - & 1923 & 925 & - & 208 \\
\hline & & LBVSA2004 (mouse 2) & Died & 7 & 29 & - & - & - & - & - \\
\hline & & LBVSA2004 (mouse 3) & Survived & - & - & - & - & 801 & - & - \\
\hline & & LBVSA2004 (mouse 4) & Died & 8 & 39 & - & - & - & - & - \\
\hline & & LBVSA2004 (mouse 5) & Died & 13 & 29 & - & - & - & - & - \\
\hline & \multirow[t]{5}{*}{ MOKV } & 252/97 (mouse 1) & Survived & - & 21 & 486 & 1410 & 859 & - & - \\
\hline & & 252/97 (mouse 2) & Died & 14 & 49 & 624 & - & - & - & - \\
\hline & & 252/97 (mouse 3) & Died & 7 & 16 & - & - & - & - & - \\
\hline & & 252/97 (mouse 4) & Died & 9 & - & - & - & - & - & - \\
\hline & & 252/97 (mouse 5) & Died & 7 & - & - & - & - & - & - \\
\hline \multirow{8}{*}{$\begin{array}{l}\text { Inoculation with } \\
10^{8} \mathrm{TCID}_{50}\end{array}$} & \multirow[t]{3}{*}{ LBV } & LBVMong2004 (mouse 1) & Survived & - & 19 & - & - & - & - & 466 \\
\hline & & LBVMong2004 (mouse 4) & Died & 7 & - & - & - & - & - & - \\
\hline & & LBVMong2004 (mouse 5) & Died & 10 & 10 & - & - & - & - & - \\
\hline & \multirow[t]{5}{*}{ LBV } & LBVAFR1999 (mouse 1) & Died & 7 & - & - & - & - & - & - \\
\hline & & LBVAFR1999 (mouse 2) & Died & 7 & 35 & - & - & - & - & - \\
\hline & & LBVAFR1999 (mouse 3) & Died & 7 & 29 & - & - & - & - & - \\
\hline & & LBVAFR1999 (mouse 4) & Died & 7 & 48 & - & - & - & - & - \\
\hline & & LBVAFR1999 (mouse 5) & Survived & - & 34 & - & 1931 & 772 & - & 1165 \\
\hline \multirow{5}{*}{$\begin{array}{l}\text { Inoculation with } \\
10 \% \text { original brain } \\
\text { suspension }\end{array}$} & \multirow[t]{5}{*}{ LBV } & LBVSA2008 (mouse 1) & Died & 14 & 34 & - & - & - & - & - \\
\hline & & LBVSA2008 (mouse 2) & Died & 14 & 16 & 264 & - & - & - & - \\
\hline & & LBVSA2008 (mouse 3) & Died & 21 & 28 & 374 & - & - & - & - \\
\hline & & LBVSA2008 (mouse 4) & Died & 14 & - & 426 & - & - & - & - \\
\hline & & LBVSA2008 (mouse 5) & $\begin{array}{l}\text { Died due to } \\
\text { handling }\end{array}$ & 7 & 21 & - & - & - & - & - \\
\hline
\end{tabular}

RABV, Rabies virus; MOKV, Mokola virus; DUVV, Duvenhage virus; LBV, Lagos bat virus.

$\dagger$, Number indicates the day the mouse died or was euthanised.

-, indicates that the mouse had died or that there was no blood collected on that day and therefore VNA was not determined.

had high mean viral RNA concentration. There was also a decrease in mean incubation period in the high mortality group when comparing LBV isolates. This could indicate that inoculation with a high dose results in the virus reaching the CNS faster, multiplying to high titre and therefore causing death more quickly. The virus titre of the $10 \%$ suspension of the original bat brain material (LBVSA2008) was not determined; therefore an increase in percentage mortality and a decrease in mean incubation period when mice were infected with this inoculum could indicate that the titre of the virus was higher than $10^{5} \mathrm{TCID}_{50}$ of the tissue culture material. Another possible reason for the difference in pathogenicity of original bat brain and tissue culture material could be that mutations may have been introduced during passage in culture which influenced pathogenicity. This could not be confirmed since no original brain material was available for sequencing. LBV (LBVSA2008) inoculation at $10^{3} \mathrm{TCID}_{50} \mathrm{did}$ not cause death as observed with our previous study, which showed some LBV isolates to be non-lethal when inoculated i.m. at $10^{3} \mathrm{LD}_{50}$ (Markotter et al. 2009).

\section{Viral RNA in the blood of mice infected with African lyssaviruses}

The occurrence of RABV in the blood of infected animals is conflicting. The virus is considered to be absent in the blood of lyssavirus infected animals (Borodina 1958; Schindler 1961). However, there are a few studies which have reported 
contradictory results to what is generally known about viremia in lyssavirus infection. Viremia was reported in RABV infected dogs (Burne 1970). Lodmell et al. (2006) also reported the presence of viral RNA in the blood of RABV infected mice. The presence of viral RNA in clinically ill mice in the study could be due to injury to organs including the blood-brain barrier, resulting in escape of the virus from the infected organs into the bloodstream. In this study, no viral RNA was detected in the blood of mice after inoculation with different African lyssavirus isolates.

\section{Viral RNA load in the brains and salivary glands of mice infected with African lyssaviruses}

There were differences in mean viral RNA concentration in the brains of mice inoculated with different virus isolates. Differences were also observed in viral RNA concentration in the brains of mice inoculated with the same isolate. This indicated that the pathogenicity of lyssaviruses does not necessarily depend on the amount of the virus in the brains of inoculated animals. No viral RNA was detected in the salivary glands of any of the infected animals, regardless of the lyssavirus species or the outcome of the infection. A number of studies reported the presence of virus in the salivary glands of rabid animals (Hughes et al. 2006; Kemp et al. 1973; Kuzmin et al. 2008; Lima et al. 2005; Shankar et al. 2004). The animal model in all these studies was different from this study, except that of Lima et al. (2005). Lima et al. (2005) reported viral RNA in the salivary glands of mice that succumbed to rabies on days 10 to 21 using hemi-nested PCR. However, there was no viral RNA in the salivary glands of mice that died on days 25 and 30. In that study, a pool of salivary glands from two to three mice was used for RNA isolation. This finding supports the studies that showed that mice are not an ideal model for pathogenesis studies of lyssaviruses (Smith 1996) and that pathogenesis studies should involve true reservoir species. However, mice are nevertheless a practical and useful first line (primary) animal model for lyssavirus research.

\section{Serological response of mice to infection with African lyssaviruses}

It was found that the natural production of VNA during infection did not correlate with survival, since there was no clear difference in the VNA titres of mice that died and those that survived. Although VNA has been shown to be important in clearance of RABV infection (Hooper et al. 1998), there are other mechanisms that also play a role in virus clearance (Hooper et al. 1998). Therefore, the presence of VNA after challenge with a virus does not necessarily guarantee survival; this was also observed by Coe and Bell (1977) and Roy et al. (2007).

\section{Relationship between pathogenic domains and pathogenicity profiles observed in mice Nucleoprotein and phosphoprotein}

LBV, MOKV and DUVV isolates were found to have a common mutation in one of the two pathogenic domains described by Masatania et al. (2011). However, the mutation is not to the same amino acid as that of the non-pathogenic strain shown by Masatania et al. (2011) and it is therefore not clear if this mutation influenced the pathogenicity of these species. The motif K/RXTQT (position 144-148) on the $\mathrm{P}$ protein was reported to be important for binding to the LC8 dynein light chain and subsequently transport to the central nervous system (CNS) (Poisson et al. 2001). MOKV isolates in this study were lethal to adult mice. FAT and Real-time PCR detected antigen and viral RNA respectively in the brains of mice that succumbed, indicating that the virus reached the CNS. This is irrespective of substitution on two of the four amino acids. MOKV also had short mean incubation period compared to RABV (mongoose variant), DUVV and LBV (LBVSA2008) which had the motif conserved. Tan et al. (2007) showed transport of RABV to the CNS with the LC8 binding motif mutated. However, disruption of LC8 binding motif resulted in non-pathogenic strains due to reduced transcription and replication and not failure to travel to the CNS (Tan et al. 2007). In this study, when $10^{5} \mathrm{TCID}_{50}$ was used, MOKV isolate (12341) had high mean viral RNA concentration in the brain as compared to LBV (LBVSA2008) and DUVV (DUVVSA06) isolates in which the LC8 binding motif was conserved.

\section{Matrix protein}

LBV (LBVAFR1999 and LBVNig1956) and MOKV (12341, 543/95 and 173/06) isolates had both residues (Lys 77 and Asn 81 ) on the M protein which were reported to increase apoptosis (Gholami et al. 2008). These mutations seemed to have little or no influence in pathogenicity in this study. LBV (LBVAFR1999) and MOKV (12341) caused 80\% and 75\% mortality to mice respectively despite having these amino acids, whilst LBV (LBVNig1956) was not lethal.

\section{Glycoprotein}

Lys/Arg 333 on the glycoprotein has been reported by a number of researchers to be important in lyssavirus pathogenicity (Badrane et al. 2001; Dietzschold et al. 1983; Takayama-Ito et al. 2006). All phylogroup II lyssavirus isolates had Arg/ Lys 333 substitution to Asp. Badrane et al. (2001) reported these isolates to be non-pathogenic i.m. in mice. However, the Badrane et al. (2001) study was limited to one isolate of LBV and MOKV. In this study, all phylogroup II lyssaviruses (with the exception of one LBV isolate, LBVNig1956) were lethal i.m., as reported by previous studies (Kemp et al. 1973; Kuzmin et al. 2008; Markotter et al. 2009). All LBV isolates except LBVAFR1999 also had Lys 330 substituted to Leu whilst MOKV isolates had this amino acid conserved. This did not result in reduced pathogenicity of the LBV isolates. In addition to these substitutions, MOKV and LBV isolates had mutations in two of the amino acids (Ala 242 and Asp 255 ) important in the pathogenicity of the Nishigahara strain whilst the third amino acid (Ile 268) was conserved. This was with the exception of LBV (LBVNig1956), which had all the three amino acids substituted. Takayama-Ito et al. (2006) 
showed the RC-HL strain with mutations on the three amino acids to be non-lethal to mice via the i.c. route, but the strain was lethal when Leu 268 was substituted by Ile as with the Nishigahara strain. This could explain why LBVNig1956 was found to be non-pathogenic whilst the other phylogroup II lyssaviruses were found to be pathogenic. MokZim isolate reported by Badrane et al. (2001) to be non-pathogenic and the MOKV isolate, 12341, in this study had the same amino acids on all currently known pathogenic domains on the $G$ protein. This shows that in addition to pathogenic domains, there are other factors that affect the pathogenicity of lyssaviruses. It could also indicate that there are other yet unidentified domains or regions that play a role in pathogenicity. RABV had less variation in the peptide fragment for acetylcholine receptor binding than LBV, MOKV or DUVV. The amino acids important in binding to the p75 neurotropin receptor were only conserved for RABV. Pathogenicity of LBV, MOKV and DUVV despite these substitutions emphasised the realisation that lyssaviruses bind to a variety of receptors.

\section{Combined effects of pathogenic domains on mortality}

Within LBV, LBVAFR1999 had most of the pathogenic domains conserved whilst LBVNig1956 had fewer than RABV. LBVAFR1999 had a higher percentage mortality and shorter incubation period than LBVMong2004 when inoculated at the same dose. This suggests some cooperativity between pathogenic domains within LBV. However, this cooperative effect was not observed when comparing the different species. RABV (canid and mongoose variants) had most of the known pathogenic domains conserved, followed by DUVV, as compared to LBV and MOKV. When inoculated at the same dose, RABV (canid variant) had the lowest percentage mortality whilst RABV (mongoose variant) and DUVV had the same percentage mortality as LBV but lower than that of MOKV. The vaccine strain, HEP-Flury had Arg 333 substitution to Qln, whilst most other pathogenic amino acids were conserved compared to LBV, MOKV and DUVV. However, this strain was reported to be non-pathogenic via both the i.c. and i.m. routes (Takayama-Ito et al. 2006). This supports our previous observation that in addition to known pathogenic domains, there are other domains or factors that contribute to the pathogenicity of lyssaviruses. This nullifies the view that a specific amino acid is important for the pathogenicity of the genus Lyssavirus based on a few isolates, especially of a single species.

\section{Conclusion}

The study supports previous studies indicating that all African lyssavirus species can be lethal when inoculated via the i.m. route and that the pathogenicity of a lyssavirus species should not be concluded based on a single isolate. Furthermore, until all pathogenic domains have been mapped and the co-operation between these domains and other cellular factors are understood, the pathogenicity of an isolate or species cannot be determined by the analysis of the amino acids encoded in domains associated with pathogenicity without inoculation in an animal model.

\section{Acknowledgements}

We wish to thank the Rabies Unit, Onderstepoort Veterinary Institute, Pretoria, South Africa, for providing the isolates, with few exceptions. DUVVSA2006 isolate was kindly provided by the Centre for Emerging and Zoonotic Diseases, National Institute of Communicable Disease (National Heath Laboratory Services), Sandringham, South Africa. LBVAFR1999 was kindly provided by Dr Cliquet from Agene Francaise de Sécurité Sanitaire des Aliments, France and LBVNig1956 by the Centers for Disease Control and Prevention, Atlanta, USA. We also thank the National Research Foundation, the International Society for Infectious Diseases, the International Foundation for Science and the Poliomyelitis Research Foundation for financial support.

\section{Competing interests}

The authors declare that they have no financial or personal relationship(s) that may have inappropriately influenced them in writing this article.

\section{Authors' contributions}

W.M. (University of Pretoria) was the project leader, L.H.N. (University of Pretoria) the project co-leader and J.K. (University of Pretoria) performed the experiments. All authors contributed to writing the manuscript.

\section{References}

Badrane, H., Bahloul, C., Perrin, P. \& Tordo, N., 2001, 'Evidence of two phylogroups with distinct pathogenicity and immunogenicity', Journal of Virology 75, 32683276. http://dx.doi.org/10.1128/JVI.75.7.3268-3276.2001, PMid:11238853

Borodina, TA., 1958, 'A study of viraemia in experimental rabies', Problems of Virology 4, 96-100.

Burne, J.C., 1970, 'Viremia in rabies', Lancet 1, 195-196. http://dx.doi.org/10.1016/ S0140-6736(70)90444-7

Coe, J.E. \& Bell, J.F., 1977, 'Antibody response to rabies virus in Syrian hamsters', Infection and Immunity 16, 915-919. PMid:330398

Coertse, J., Weyer, J., Nel, L.H. \& Markotter, W., 2010, 'Improved PCR methods for the detection of African rabies and rabies-related lyssaviruses', Journal of Clinical Microbiology 48, 3949-3955. http://dx.doi.org/10.1128/JCM.01256-10, PMid:20810772

Cohen, C., Sartorius, B., Sabeta, C., Zulu, G., Paweska, J., Mogoswane, M. et al., 2007, 'Epidemiology and molecular virus characterization of reemerging rabies, South Africa', Emerging Infectious Diseases 13, 1879-1886. http://dx.doi.org/10.3201/ eid1312.070836, PMid:18258039

Coulon, P., Ternaux, J-P., Flamand, A. \& Tuffereau, C., 1998, 'An avirulent mutant of rabies virus is unable to infect motoneurons in vivo and in vitro', Journal of Virology 72, 273-278. PMid:9420224

Dean, D.J., Abelseth, M.K. \& Atanasiu, P., 1996, 'The fluorescent antibody test', in F.X. Meslin, M.M. Kaplan \& H. Koprowski (eds.), Laboratory techniques in rabies, pp. 88-95, World Health Organization, Geneva. PMid:8788270

Dietzschold, B., Wunner, W.H., Wiktor, T.J., Lopes, A.D., Lafon, M., Smith, C.L. et al., 1983, 'Characterization of an antigenic determinant of the glycoprotein that correlates with pathogenicity of rabies virus', Proceedings of the National Academy of Sciences of the United States of America 80, 70-74. http://dx.doi. org/10.1073/pnas.80.1.70, PMid:6185960

Dietzschold, B., Li, J., Faber, M. \& Schnell, M., 2008, 'Concepts in the pathogenesis of rabies', Future Virology 3, 481-490. http://dx.doi.org/10.2217/17460794.3.5.481, PMid:19578477

Faber, M., Faber, M.L., Papaneri, A., Bette, M., Weihe, E., Dietzschold, B. et al., 2005 'A single amino acid change in rabies virus glycoprotein increases virus spread and enhances virus pathogenicity', Journal of Virology 79, 14141-14148. http:// dx.doi.org/10.1128/JVI.79.22.14141-14148.2005, PMid:16254349

Gholami, A., Kassis, R., Real, E., Delmas, O., Guadagnini, S., Larrous, F. et al., 2008 'Mitochondrial dysfunction in lyssavirus-induced apoptosis', Journal of Virology 82, 4774-4784. http://dx.doi.org/10.1128/JVI.02651-07, PMid:18321977 
Hall, T.A., 1999, 'BioEdit: A user-friendly biological sequence alignment editor and analysis program for Windows 95/98/NT', Nucleic Acids Symposium Series 41 95-98.

Hooper, D.C., Morimoto, K., Bette, M., Weihe, E., Koprowski, H. \& Dietzschold, B., 1998, 'Collaboration of antibody and inflammation in clearance of rabies virus from the central nervous system', Journal of Virology 72, 3711-3719. PMid:9557653

Hughes, G.J., Kuzmin, I.V., Schmitz, A., Blanton, J., Manangan, J. \& Murphy, S. et al., 2006, 'Experimental infection of big brown bats (Eptesicus fuscus) with Eurasian bat lyssaviruses Aravan, Khujand and Irkut virus', Archives of Virology, 2021-2035. http://dx.doi.org/10.1007/s00705-005-0785-0, PMid:16705370

International Committee on Taxonomy of Viruses, ICTV official taxonomy: updates since the 8th report. Vertebrate International Committee on Taxonomy of Viruses, viewed 08 June 2012, from http://talk.ictvonline.org/files/ictv official taxonomy_updates_since_the_8th_report/m/vertebrat 2012/06/08.aspx

Irie, T., Carnero, E., Okumura, A., García-Sastre, A. \& Harty, R.N., 2007, 'Modification of the PSAP region of the matrix protein lead to attenuation of vesicular stomatitis virus in vitro and in vivo', Journal of General Virology 88, 2559-2567. http:// dx.doi.org/10.1099/vir.0.83096-0, PMid:17698667

Jackson, H.Y., Phelan, C.C., Ridaura-Sanz, C., Zheng, Q., Li, Z., Wan, X. et al., 1999, 'Extraneural organ involvement in human rabies', A Journal of Technical Methods and Pathology 79, 945-951.

Kemp, G.E., Moore, D.L., Isoun, T.T. \& Fabiyi, A., 1973, 'Mokola virus: Experimental infection and transmission with the shrew, a natural host', Archiv für die gesamte Virusforschung 43, 242-250. http://dx.doi.org/10.1007/BF01250419, PMid:4772939

Knobel, D., Cleaveland, S., Coleman, PG., Fevre, E.M., Meltzer, M.I., Miranda, M.E.G. et al., 2005, 'Re-evaluating the burden of rabies in Africa and Asia', Bulletin of the World Health Organisation 83, 360-368. PMid:15976877

Kuzmin, I.V., Niezgoda, M., Franka, R., Agwanda, B., Markotter, W., Beagley, J.C. et al., 2008, 'Lagos bat virus in Kenya', Journal of Clinical Microbiology 46, 1451-1461. http://dx.doi.org/10.1128/JCM.00016-08, PMid:18305130

Kuzmin, I.V., Mayer, A.E., Niezgoda, M., Markotter, W., Agwanda, B., Breiman, R.F, et al., 2010, 'Shimoni bat virus, a new representative of the lyssavirus genus', Virus Research 149, 197-210. http://dx.doi.org/10.1016/j.virusres.2010.01.018, PMid:20138934

Langevin, C., Jaaro, H., Bressanelli, S., Fainzilber, M. \& Tuffereau, C., 2002, 'Rabies virus glycoprotein (RVG) is a trimeric ligand for the N-terminal cysteine-rich domain of the mammalian p75 neurotrophin receptor', The Journal of Biological Chemistry 277, 37655-37662. http://dx.doi.org/10.1074/jbc.M201374200, PMid:12163480

Lentz, T.L., Wilson, P.T., Hawrot, E. \& Speicher, D.W., 1984, 'Amino acid sequence similarity between rabies virus glycoprotein and snake venom curaremimetic neurotoxins', Science 226, 847-848. http://dx.doi.org/10.1126/science.6494916, PMid:6494916

Lima, K.C., Megid, J., Silva, A.V. \& Cortez A., 2005, 'The heminested RT-PCR for the study of rabies virus pathogenesis', Journal of Virological Methods 124, 79-85. $\mathrm{http}: / / \mathrm{dx}$.doi.org/10.1016/j.jviromet.2004.11.008, PMid:15664054

Lodmell, D.L., Dimcheff, D.E. \& Ewalt, L.C., 2006, 'Viral RNA in the bloodstream suggests viremia occurs in clinically ill rabies-infected mice', Virus Research 116 114-118. http://dx.doi.org/10.1016/j.virusres.2005.09.004, PMid:16242805

Markotter, W., Kuzimin, I., Ruprrecht, C.E., Randles, J., Sabeta, C.T., Wandeler, A.I. et al., 2006a, 'Isolation of Lagos bat virus from water mongoose', Emerging
Infectious Diseases 12, 1913-1918. http://dx.doi.org/10.3201/eid1212.060514, PMid:17326944

Markotter, W., Randles, J., Rupprecht, C.E., Sabeta, C.T., Wandeler, A.I., Taylor, P.J. et al., 2006b', 'Recent Lagos bat virus isolations from bats (suborder Megachiroptera) in South Africa', Emerging Infectious Diseases 12, 504-506. http://dx.doi. in South Africa', Emerging Infectious Diseases
org/10.3201/eid1203.051306, PMid:16704795

Markotter, W., Kuzmin, I., Rupprecht, C.E. \& Nel, L.H., 2008, 'Phylogeny of Lagos bat virus: Challenges for lyssavirus taxonomy', Virus Research 35, 10-21. http:// dx.doi.org/10.1016/j.virusres.2008.02.001, PMid:18359532

Markotter, W., Kuzmin, I.V., Rupprecht, C.E. \& Nel, L.H., 2009, 'Lagos bat virus virulence in mice inoculated by the peripheral route', Epidemiology and Infection 137, 1155-1162. http://dx.doi.org/10.1017/S0950268808001945, PMid:19144249

Marston, DA., Horton, DL., Ngeleja, C., Hampson, K., McElhinney, LM., Banyard, AC. et al., 2012, 'Ikoma lyssavirus, highly divergent novel lyssavirus in an African civet', Emerging Infectious Diseases 18, 664-667. http://dx.doi.org/10.3201/ eid1804.111553, PMid:22469151
Masatania, T., Ito, N., Shimizua, K., Ito, Y., Nakagawaa, K., Abea, M. et al., 2011, 'Amino acids at positions 273 and 394 in rabies virus nucleoprotein are important for both evasion of host RIG-I mediated antiviral response and pathogenicity', Virus Research 155, 168-174. http://dx.doi.org/10.1016/j.virusres.2010.09.016, Research 155
PMid:20875468

Mita, T., Shimizu, K., Ito, N., Yamada, K., Ito, Y., Sugiyama, M. et al., 2008, 'Amino acid at position 95 of the matrix protein is a cytopathic determinant of rabies virus', Virus Research 137, 33-39. http://dx.doi.org/10.1016/j.virusres.2008.05.011, Virus Research

Nakahata, Y., Akashi, M., Trcka, D., Yasuda, A. \& Takumi, T., 2006, 'The in vitro realtime oscillation monitoring system identifies potential entrainment factors for time oscillation monitoring system identifies
circadian clocks', BMC Molecular Biology 7.

Nel, L.H., Sabeta, C.T., Von Teichman, B., Jaftha, J.B., Rupprecht, C.E. \& Bingham, J., 2005, 'Mongoose rabies in southern Africa: A re-evaluation based on molecular 2005, 'Mongoose rabies in southern Africa: A re-evaluation based on molecular
epidemiology', Virus Research 109, $165-173$. epidemiology', Virus Research 109, $165-173$.
org/10.1016/j.virusres.2004.12.003, PMid:15763147

Niezgoda, M., Briggs, D.J., Shaddock, J., Dreesen, D.W. \& Rupprecht, C.E., 1997, 'Pathogenesis of experimentally induced rabies in domestic ferrets', American Journal of Veterinary Research 58, 1327-1331. PMid:9361901

Niezgoda, M., Briggs, D.J., Shaddock, J. \& Rupprecht, C.E., 1998, 'Virus excretion in domestic ferrets (Mustela putorius furo) inoculated with a raccoon rabies isolate', American Journal of Veterinary Research 95, 1629-1632.

Poisson, N., Real, E., Gaudin, Y., Vaney, M-C., King, S., Jacob, Y. et al., 2001, 'Molecular basis for the interaction between rabies virus phosphoprotein $\mathrm{P}$ and the dynein light chain LC8: Dissociation of dynein-binding properties and transcriptional functionality of $\mathrm{P}^{\prime}$, Journal of General Virology 82, 2691-2696. PMid:11602781

Reed, L.J. \& Muench, H., 1983, 'A simple method of estimating fifty percent endpoints', American Journal of Hygiene 27, 493-497.

Roy, A., Phares, T.W., Koprowski, H. \& Hooper, D.G., 2007, 'Failure to open the bloodbrain barrier and deliver immune effectors to central nervous system tissues leads to the lethal outcome of silver-haired bat rabies virus infection', Journal of Virology 81, 1110-1118. http://dx.doi.org/10.1128/JVI.01964-06, PMid:17108029

Sabeta, C.T., Blumberg, L., Miyen, J., Mohale, D.K., Shumba, W. \& Wandeler, A.I., 2010, 'Mokola virus involved in a human contact (South Africa)', FEMS Immunology and Medical Microbiology 58, 85-90. http://dx.doi.org/10.1111/j.1574695X.2009.00609.x, PMid:19817861

Schindler, R., 1961, 'Studies on the pathogenesis of rabies', Bulletin of the World Health Organization 25, 119-126. PMid:14498436

Seif, I., Coulon, P., Rollin, PE. \& Flamand, A., 1985, 'Rabies virus virulence: Effect on pathogenicity and sequence characterization of mutations affecting antigenic site III of the glycoprotein', Journal of Virology 53, 926-935. PMid:2579247

Shankar, V., Bowen, R.A., Davis, A.D., Rupprecht, C.E. \& O'Shea, T.J., 2004, 'Rabies in a captive colony of big brown bats (Eptesicus fuscus)', Journal of Wildlife Diseases 40, 403-413. PMid:15465706

Smith, J.S., 1996, 'New aspects of rabies with emphasis on epidemiology, diagnosis, and prevention of the disease in the United States', Clinical Microbiology Reviews 9, 169-175.

Takayama-Ito, M., Ito, N., Yamadaa, K., Sugiyama, M. \& Minamoto, N., 2006, 'Multiple amino acids in the glycoprotein of rabies virus are responsible for pathogenicity in adult mice', Virus Research 115, 169-175. http://dx.doi.org/10.1016/j. virusres.2005.08.004, PMid:16188341

Tan, G.S., Preuss, M.A.R., Williams, J.C. \& Schnell, M.J., 2007, 'The dynein light chain 8 binding motif of rabies virus phosphoprotein promotes efficient viral transcription', Proceedings of the National Academy of Sciences of the United States of America 104, 7229-7234. http://dx.doi.org/10.1073/pnas.0701397104, PMid:17438267

Van Eeden, C., Markotter, W. \& Nel, L.H., 2011, 'Molecular phylogeny of Duvvenhage virus', South African Journal of Science 107, 1-5. http://dx.doi.org/10.4102/sajs. v107i11/12.177

Warrell, MJ. \& Warrell, DA., 2004, 'Rabies and other lyssavirus diseases', Lancet 363 , 959-959. http://dx.doi.org/10.1016/S0140-6736(04)15792-9

Wirblich, C., Tan, G.S., Papaneri, A., Godlewski, P.J., Orenstein, J.M., Harty, R.N. et al., 2008, 'PPEY motif within the rabies virus (RV) matrix protein is essential for efficient virion release and RV pathogenicity', Journal of Virology 82, 9730-9738. http://dx.doi.org/10.1128/JVI.00889-08, PMid:18667490 